Original Research Paper

\title{
The Main Features of Translations of Foreign Literature by Jusupbek Aimautuly: Cultural and Historical Differences
}

\author{
Amanzhol Altay, Saulesh Aituganova and Karlygash Aubakirova \\ Department of Philology, L. Gumilyov Eurasian National University, Astana, Kazakhstan
}

\author{
Article history \\ Received: 02-11-2015 \\ Revised: $17-11-2015$ \\ Accepted: 04-12-2015 \\ Corresponding Author: \\ Karlygash Aubakirova \\ Department of Philology, L. \\ Gumilyov Eurasian National \\ University, Astana, Kazakhstan \\ Email: aubakirovakarlygash@gmail.com
}

\begin{abstract}
This article analyzes characteristics of translations of American, French and Indian literature into Kazakh. The authors examine translations of the works of Rabindranath Tagore and Ferdinand Duchenne into the Kazakh language and describe the style of translation, motives for translation and cultural differences revealed by translation. Using the scientific method of content analysis, the authors show a quantitative imbalance between originals and their translations and attribute this to the historical, cultural and ethical differences.
\end{abstract}

Keywords: Translation, Cultural Differences, Kazakh Literature, Historical Background

\section{Introduction}

The beginning of the XX century left a special mark on the spiritual and cultural life of the Kazakh people. This period of time can be called a confluence of traditional and modern. Thus the writers of that time were facing a special challenge: To skillfully get across significant changes and news that occurred in the world community that impacted the spiritual world of man. Great things accomplished in those times include the revival of the Kazakh people by the representatives of Alash (the common name of all Kazakh people), the call for education and science, efforts into the development of literature, language, and the publishing sphere, and inspiration toward the ideas of independence. At that time, all Alash intellectuals and activists spared no effort for the brighter future of the Kazakh people. Leaders who cared about their people like J. Aimautuly, A. Baitursynov, A. Bokeyhanov, M. Dulatov invested their hearts and strength to make the right choice for the future path of the Kazakh people. In the works of these well-known individuals one can often find both early literary traditions and signs of a developing national literary language. We can therefore say that the writers of that time are great figures who opened up the way for the development of national literature, who-despite the troubled times and all difficulties-were developing the literature they inherited. The literary process of this period served as the expression of social justice and a demand for satisfaction by the people. To awaken the people, who had been under the yoke of the Russian Empire and oppressed to exhaustion, Alash figures were trying to raise the spirituality of the people as much as possible. As D. Kamzabekuly said: "The only choice of that time was to prevent any chance of the disappearing of the national spirit" (Kamzabekuly, 2002). They felt responsible for the fate of their people and determined the prevention of the disappearance of the national spirit to be the primary task; they set a goal to actively promote and preserve the traditional life of the Kazakh people and made an enormous contribution to the development of great spiritual power. This united the nation in the development of a powerful, artistic and aesthetic literature.

In this article, we would like to focus on Jusupbek Aimautuly-a great figure who faithfully served the spiritual life and culture, science and education of the Kazakh people, a possessor of a huge talent. His contributions are perpetuated in every area. This is because he is, firstly, a writer, a person who raised Kazakh prose to its peak; secondly, a great publicist and a public figure who paid attention to and participated in the political, cultural, spiritual and social life of his people; thirdly, a translator who made a great contribution to the art of Kazakh translation by translating well-known works of world literature into Kazakh; fourthly, a playwright, fifthly, a research psychologist, sixthly, a professional teacher who promoted education for people, seventhly, a critic who oversaw the proper development of the Kazakh literature. 
Among Jusupbek Aimautuly's diverse works of particular importance and benefit to Kazakh literature is his translations. Translation is an art originating from the time of the Sumerian civilization, which appeared earlier than written literature and is an art that has taken deep roots. Translation is a beaten track allowing one to get acquainted with the best works of world literature; translation is the basis of cultural ties which bring together different peoples and their spiritual world view. Therefore translation serves as a link between culture and literature. If the mediator between God and man was the angel Gabriel, then translators are spiritual mediators between two nations. Realizing the importance and necessity of translation, Jusupbek Aimautuly appreciated translation as a great art and treated it with respect and great responsibility. $\mathrm{He}$ made a significant contribution to the development of translation studies since he had translated the best classics of Russian and Western literature, thus paving the way for cultural ties between peoples. He was able to appreciate the impact of translation on an author's writing skills, introducing Kazakh readers to classical masterpieces of such masters of the art as Jack London, Rabindranath Tagore, Conrad Berkowitz, Guy de Maupassant, Gorky, and Pushkin. As a professional translator, J. Aimautuly through literature contributed to the formation of universal values, through spiritual and cultural communication he has given a new round to the development of literature and contributed to the rise of Kazakh literature onto a qualitatively new level. He spared no effort to develop Kazakh thought, for its revival and for the aspirations of his people to equality in a society that was suffering from tyranny and violence. To do this, he translated stories resonating with the grief and sorrow of the Kazakh people of that time.

Aimautuly gave a special place to the translational art in Kazakh literature, which is clearly demonstrated in his words: "It is impossible to identify your weaknesses and peculiarities without getting acquainted with the literature of another country and without comparing the characteristics of your nation with those of other nations" (Aimautuly, 1925). He never translated a work randomly; he first of all analyzed and carefully chose for translation a work whose content appealed to his goals.

\section{Methods of Research}

In this study we used various research techniques to portray an objective picture of the historical reality of the 1920-30s and that helped to shape the main reasons for the translation of works of foreign authors into the Kazakh language and identify some of the aspects and features of translation.
Key findings of the research were obtained through the use of the biographical method and the culturalhistorical, comparative-historical and comparativecontrastive methods. The use of these research methods is conditioned by the study of Aimautuly's workstranslations from various countries, written by authors with different biographical data and socio-cultural backgrounds. Translations by Aimautuly of «Thamilla» by Ferdinand Duchenne and "Balzhan" by Rabindranath Tagore were subjected to a deep analysis.

At the same time we used the method of content analysis to examine 6 translated texts in Russian, Kazakh and in the language of the original and revealed more than 1,000 instances that have undergone a subsequent and substantial interpretation.

\section{Results}

\section{Aimautuly's Story "Balzhan", Rabindranath} Tagore's Translated Work

Jusupbek Aimautuly is one of Kazakhstan's greatest writers, who lived on the border of two eras of social change and unrest that took place at the beginning of the XX century; a writer who managed to describe with an outstanding artistry the truth of that troubled time in literary language (Kirabayev, 2002). With his proficiency in two languages and his inherent poetic talent and oratory, Jusupbek Aimautuly, while translating works of other nations, dwelt carefully and selectively on those works that were more similar to the perception and identity of the Kazakh people, revealing similar problematic situations for the Kazakh society and bringing ideas for reflection. He did not try to translate a work precisely and did not give a correct copy; he was rather inclined to the dramatic and close to his reader, giving a work some national colors. For example, in J. Aimautuly's translations we find stories about women's problems. It was one of the main concerns of Kazakh society of the time. Raising women's issues to the socio-political level, J. Aimautuly proves that he was a high-degree humanist. A special place in Jusupbek's public worldview is given to women's equality. The writer spared no effort to raise the role of Kazakh women in society and the family to a high level and to change traditional attitudes. In his storyies and plays such as "AkBilek" and "Kunikeydyn Zhazygy" he comprehensively describes the fate of women in Kazakh villages. In these works the writer was trying to prove the lack of formation in their social situation, which should protect the equal rights of women in the Kazakh society.

Fully aware of the complexity of the problems of women, Aimautuly touched on this issue in his translational work as well. Here we refer to the story of the writer "Balzhan" which was translated from 
Rabindranath Tagore's work. Through this translation we can see how much J. Aimautuly wanted to solve the problems of women in Kazakh society.

Now let us consider the author of the original storyRabindranath Tagore. Tagore was born on May 7, 1861 in the Indian city of Kolkata and he died there on August 6, 1941. At the age of 14, he published his first poem. His father, Debendronath Tagore, was a leader in the social religious organization "BrahmoSamaj". This organization was created at the initiative of Ram Mohan Rai in the XIX century. After Ram Mohan Rai's death the organization was headed by Tagore' father. On this and on what kind of organization "BrahmoSamaj" was, the Indian scientist P. Mahalanobis said the following: "BrahmoSamaj' is a great social and religious movement which was headed by Ram Mohan Rai in the early XIX century. This movement broke the shackles of religious prejudices and harsh customs of the Indian society at the time. After Ram Mohan Rai's death 'BrahmoSamaj' was Debendronath Tagore, Rabindranath's father. The society 'BrahmoSamaj' was engaged in preaching theistic ideas and the brotherhood of all people on earth; it totally rejected idolatry and infallibility of the Vedas (and other holy books) and did not recognize caste distinctions; it proclaimed the equality of men and women, the equality of all castes, races and nations" (Tagore, 1961). Being the son of such a public figure, Rabindranath grew up among religious, political, cultural information and remains in history as a person who honestly and faithfully served his people.

Rabindranath Tagore, a poet and a writer who brought to awareness of the inner world, identity and state of the Indian people to the entire world through his works; he is a person who has made a huge contribution to the development of human culture and he is a figure who whole-heartedly served the prosperity of the Indian people and their development. A Nobel Prize Winner, Indian scientist Sh. Chatterdzhi, in his extensive article "What has Rabindranath Tagore done for India", says: "With his literary and musical compositions, his inexhaustible contribution to the revival of the spiritual life of the country, his lectures, his social cultural and educational activities and finally his personality, through a direct contact with thousands of people, he was able to bring about a completely new and fresh stream into the life of the entire India" (Tagore, 1961).

R. Tagore also participated in the education of the people. He was a teacher, published books, participated actively in the political and social affairs of the society, published articles, composed music for about 200 songs, was the founder of music schools in the Indian territory and laid the foundation of the Indian drama by writing plays. At the age of 65 he mastered the art of painting, in the 1930s there were exhibitions of his drawings and paintings in Paris, Berlin, London, New York and Moscow (Momyshuly, 1961). Thus the merit of the poet, writer, playwright, painter, musician, teacher, educator and politician Tagore for his nation is the size of the ocean. From this point of view the two people's honored figures J. Aimautuly's and R. Tagore's objectives, goals, dreams, care for their peoples and service for their nations are mutually harmonious and similar. If we consider the similarity of the content of their works aimed at solving the most complex problems, it becomes clear why J. Aimautuly referred to Rabindranath Tagore as his favorite writer while completing a questionnaire. If we count only Rabindranath's stories, there are more than 100 of them. Jusupbek translated among them the story "Subha", renaming it as "Balzhan" and in 1926 he published it in the pages of the newspaper "Leninist Youth", issues №1 and 2. Rabindranath Tagore also chose for some of his stories the problem of women in the Indian society. His works widely describe the suffering of Indian women from traditional marriage, the plight of widows and strict traditions for marrying off women, etc.

The presentation of R. Tagore's story "Subha" with a Kazakh girl's name as well as with other characters given Kazakh names coordinates the fates of the Indian and Kazakh girls and shows J. Aimautuly's translations skills. The total content of this story is devoted to the life of a mute girl. The author shows how parents do not consider their daughter's opinion when marrying her off and comprehensively described the misunderstanding of her soul. In the story J. Aimautuly translated the name "Shubhashinias "Baltildi" ("Honey Tongue") (Aimautuly, 1926). The story begins as the following:

"When she was given the name Shubhashini,
which means "speaking beautifully", who
could have thought that the girl would be
dum? She had two older sisters. Their names
were Shukeshini and Shuhashini. Thus the
father decides to give his youngest daughter a
name that starts with the same word "shu”-
beautiful, marvelous. In the family
Shubhashini was called simply Shubha."
"Баланың атын Балтілді қойванда, сақау
болады деген кімнің есінде бар? Екі
апасының аттары: Бірі Сұлушаш, бірі
Күлімкөз болван сон, соларва
ұйқастырвалы, әкесі кенже қызын Балтілді
қойып еді. Еркелетіп Балжандеуші еді».

"When she was given the name Shubhashini, which means "speaking beautifully", who could have thought that the girl would be dum? She had two older sisters. Their names were Shukeshini and Shuhashini. Thus the father decides to give his youngest daughter a name that starts with the same word "shu"beautiful, marvelous. In the family Shubhashini was called simply Shubha."

«Баланың атын Балтілді қойванда, сақау болады деген кімнің есінде бар? Екі Бірі Сулушам, бірі ұйқастырвалы, әкесі кенже қызын Балтілді қойыn еді. Еркелетіп Балжан деуші еді». 
"When the girl was named "Baltildi" who could have thought that she would be dumb? And the father decided to name his youngest daughter as Baltildiso that he would be like her sisters, one of whom was named Sulushash and the other Kulimkoz. Everybody called her affectionately Balzhan."

As we see, Jusupbek Aimautuly retained the basic content of the original story, but at the same time his story turned into a new work. For example, considering the meaning of the word "shu" or "beautiful", which is the first part of the names Shukeshini, Shuhashini and Shubhashini, he offered a successful analogy from the Kazakh language. The names Sulushash and Kulimkoz mean for the Kazakh people the beauty and attractiveness of a young woman. The writer, knowing that Kazakhs would never give a person the name "Baltildi", in order to save the content of the original story successfully used the name "Balzhan" and called the story by the name of the young Kazakh woman "Balzhan" rather than "Baltildi".

Along with this, the writer gave Kazakh names to the girl's father, their village, to a friend and even to cows:

"The village in which Shubha lived was called Chondipur. The river that flowed there was a usual small river Bengel."

"The aul where Balzhan lived was called Shanduer. The river that flowed there was a usual small river, which are quite numerous in Bengal.

"Banikontho's land spread down to the river and boatmen that were sailing past could see a thatched shed, barn, cowshed and a fenced garden."

“Baikadam's house (Balzhan's father) was at the river and boatmen that were sailing past could see Baikadam's shed lying open."

"Subha cannot be said to have no friends. In the barn there were two cows, Shorboshi and Panguli. They never heard their name from the lips of the girl, but very well knew her steps."

"However we cannot say that Balzhan had no friends. In the barn there were two cows: Zhantak and Meskaryn. They never heard their name from Balzhan's lips, but very well knew her steps."

"Shubha had a friend among the beings of a higher order. It was difficult to say what exactly connected them-as Shubha's friend could speak. Protap, Gonshai's younger son, was a very lazy boy. Protap's favorite pastime was fishing and almost always he could be found with a fishing rod at the river."

"Balzhan had a friend among the beings of a higher order. It was difficult to say what exactly connected them. After all, he could speak and did Balzhan have a tongue to communicate with a human being? It was Usain Altay's lazy younger son. Altay's favorite pastime was fishing and all his time he spent fishing."

As we have already said, the story is devoted to the fate of the youngest daughter of the man named Baikadam who was born dumb. In this story, there is a skillful description of Balzhan's torment due to her congenital illness, the indifference of her own mother who instead of sharing her unhappiness dooms her to loneliness:

"The daughter was born a burden. Though she married off her elder daughters with fanfares and with a rightful dowry, her youngest one remained in the family and thus condemned her parents to thinking. People think that if she is just dumb, she is blind. Dumb Balzhan becomes a disgrace to her mother. Who knows, the poor old man may have felt pity for her but he never deprived her of her due share as well as his other daughters. Helovedhereven more. Buther mother hated her the most...Balzhan gradually matured. Gradually she became smarter and more serious. New thoughts raged inside her like a blue sea during the full moon and could not break away. Balzhanin deep thoughts asked herself about something, but he could not find an answer...Balzhan reached an endless loneliness. Her heart was becoming heavier than lead. What was she to do, she could not speak. She could only remain silent at the skirt of her wild shortspoken mother."

In the story there is the enormous suffering of parents who have a daughter left on the shelf and the actions of parents who in every way try to marry off a dumb daughter, thereby seeking methods of getting rid of her:

"Parents are concerned by the thoughts of debts which they undertook to marry off their daughters and the neighbors gloat. Rumor has it that they want to expel them from society. Baikadam's home is a well-off 
house where they eat fish even twice a day. Such a home is probably to have more enemies than friends. As a result, now women intervened in the matter. Baikadam has disappeared for a few days. Returning from the trip, he was getting ready for another, saying, "We're going to Kalkutty." Sohe was going to a foreign land... With a fear of the unknown that tormented her soul, like a bull with a shut mouth Balzhan followed their parents. With her rounding big eyes she constantly stared at the faces of her parents like a person who wanted to ask about something. Parents did not say a word."

Further we read about Balzhan's internal torment that no one could share her pain of longing, thus causing the reader to be compassionate:

\begin{abstract}
"Baikadam after an afternoon nap was smoking cigarettes staying in bed. Balzhan fell sobbing at her father's feet and looked right in his eyes. Baikadam soothed her. He was also crying... Balzhan came into the cowshed to hug her childhood friends.
\end{abstract}

She treated them to hay with her hands. She embraced them all one after another and looked them in the eyes... Leaving the house she fell into the arms of the green meadows on the bank of her favorite river. The majestic land was now a silent mother to her. Embracing the mother-land, it was as if she asked, "Do not let me go, mama! Just like I embraced you, please, embrace me in your hands and do not let go!" But Balzhan's fate after the farewell with her parents is even more sorrowful:

\begin{abstract}
"After ten days, the young bride was given a nickname-mute. Balzhan is not guilty before those who did not know about her dumbness, she did not intend to deceive anyone. The fact that she is dumb was betrayed by her eyes. But no one knew that. Looking around, Balzhan could not find a single soul that can talk to her in a familiar language. There were no animals that grew up with it and could understand the language of the dumb girl. In her silent heart there now lived an unfathomable and boundless bitterness. This bitterness was heard only by a heart doctor. This time, Balzhan's master checked not only eyes and ears when he chose another young wife who could talk."
\end{abstract}

From the above passages we see how skillfully the author describes the defenseless fate of a dumb girl, her pitiable condition that reaches the very depth of human feelings. It seems that J. Aimautuly intentionally chose this story out of more than 100 of R. Tagore's works, taking into account available traditions in the Kazakh society as well as in the Indian one relating to parents' shame for unmarried daughters. This is first. Second, that period for Kazakh society was a time that did not take into account the problems of disabled women and their place in the social environment. With this story $\mathrm{J}$. Aimautuly tried to explain that people with injuries have their own dreams, their own desires, their own secrets that they want to live out as full-fledged people and about the importance of handling them with care.

When translating the story J. Aimautuly used words and phrases in the form of national titles and concepts to bring the essence closer to the Kazakh reader. For example, it is known that Indian girls never braided their hair in two braids and never decorated them with pendents (sholpy); Indian brides never waited for their bridegrooms behind a curtain. But in the story while introducing the image of the Kazakh girl Balzhan, the Indian girl Shubha is given qualities inherent to Kazakh girls:

\section{"After a few days in one of the houses in Calcutcity Balzhan's mother was dressing her with a special reverence. She braided her hair into thin braids and decorated them with pendents."}

"The bridegroom came to see the bride. Behind the curtain there was mother who joined her daughter to say her instructions but instead burst into more tears.",

We also frequently come across phrases denoting exceptionally Kazakh traditions "қызын құттыл жеріне қондыру, кісі киік болу, тонның ішкі бауындай, оймақ ауыз, аттай тулау, аузын буган өгіздей, көз шырымын алу, сәрсенбінің сәтті күні" which are impossible to translate into English.

\section{Aimautuly's Story "Dameli" Translated from $F$. Dyushen's "Thamilla"}

Another Aimautuly's translations dedicated to women's equality is the novel "Thamilla" by Ferdinand Duchenne. By the way, in many works such as candidate and doctoral dissertations, we find erroneous information claiming as fact that Aimautuly translated Alexandre Dumas' work called "Thamilla". Firstly, Dumas doesn't have a work called "Thamilla" and secondly, Jusupbek Aimautuly himself said that he had translated F. Duchenne's novel "Thamilla". 
Ferdinand Duchenne's original 1921 novel "Thamilla" begins with the words "Praise be to Allah, may He be exalted." However, in view of the sacred relationship to God, the religious situation in the Kazakh steppe and the strict censorship of the Soviet Union, Jusupbek Aimautuly removed this part from his translation (Aimautuly, 1928).

The mediator here was the Russian version of the novel "Thamilla", published in 1926 in an edition of the "Thought" by the Russian translator Trotskaya. The Kazakh translation was published by Jusupbek Aimautuly entitled "Dameli" in 1928.

French literature divides the post-war writers into three groups: Cosmopolitan, nationalist and colonial literature. Among these three groups, Ferdinand Duchenne is a noted member of the first group.

Ferdinand Duchenne for many years served in Algeria and is a French writer who knowingly described true-life situations of the Arabs. Algeria had long been under French control. Duchenne openly pointed out what he saw as the shortcomings of the Muslim religion, the existing social violence and brutality that emerged as a result of sharia laws. Through the actions of his character he skillfully conveys the importance of education, without which a society is exposed to ignorance and the importance of education as a science contributing to the formation of a good society. You can also note that in describing the plight of Arab women, there emerges the idea that the hidden motive of the French colonization policy was the following: "We are neither colonizers nor conquerors. We only expand humanity and culture" (Aimautuly, 1928). However we cannot one-sidedly look at this work of literature as politicized, because it raises issues of public indifference, ignorance and violence that occur as a result of ancient traditions of the Arab people, the diverse lives of Arab women and social inequalities. Along with the writer's skill that sincerely conveys the inner state of mind and the feelings of characters, Duchenne's work "Thamilla" describes a diverse fate of a young woman named Thamilla, the daughter of an ignorant rich man named Meziane. The father trades his daughter like cattle; besides separating his daughter from her husband, he marries her off a second time, but in the end he simply turns her out. This is a particularly significant work which shows human psychology by children's screaming loud "you, beggar tramp" and ends with the "death of the beggar tramp". Of particular importance in revealing the relationship between a man and a woman are family canons". In this study which sequentially conveys the shortcomings of Muslims, we undoubtedly understand the author's attitude to the Sharia by reading such his words in the preface, "Praise be to Allah, may He be exalted!" and the theme "You can make your wife anything but a corpse".
As a first step, what can be noted in the saying which lets us call Sharia laws "absurd" while the preface begins with the words" Praise be to Allah" which show respect for the Islamic religion? This is also a recurring theme. However, as a representative of Christianity Duchenne blames the strict laws of the old society and social inequality for the life of a young woman suffering from ignorance. By means of literature he skillfully describes the heartfelt cry of a young woman who was a victim of the old tradition, her unhappy life and internal grief from loneliness. There are political motives in this work as well. The main reason for the repeated translation into Russian and frequent editions may be the fact that Russians as well as the French were colonizers. Like the French, Russians were also Christians and the states colonized by them were Kazakh, Kyrgyz, Tatar and other Muslim states. Both authors, thinking in a similar way about the political ideology convey their thoughts exactly and precisely. If you want to know why Jusupbek Aimautuly, being a Muslim, not a Christian, chose this work, it is important to pay attention to the following.

Jusupbek Aimautuly in the preface personally explains the reason for choosing this work:

"... For the prosperity of fiction, we need to
look to the outstanding talents of Europe. You
cannot be afraid of a foreignliterature. At
least we shall know what we have achieved by
comparison..."

He also shows the main reason for choosing this work as follows:

".... written by Duisen (Duchenne) is the
beingness and life of Bedouins that empty
Haiji's pockets causing them to cry bitterly.
Their way of life, traditions and characters
are similar to Kazakhs. They also marry their
daughters off for dowry and think polygamy
as common. They are also lazy and ignorant.
Their Hajjis, mullahs, imams also lie
distorting the Sharia...The worst thing is that
Bedouin men are masters for women..."

And so Jusupbek Aimautuly revealed the real reason for the translation of Dameli and the reason is the similarity of the characters of the Kazakhs and the Arabs, who under the cover of sharia, distort it by their ignorance and illiteracy, showing similarity in social conflict and social inequality.

In Table 1 we can see the way Jusupbek Aimautuly did his translation, as well as differences between the original and the Kazakh translation. 


\begin{tabular}{|c|c|c|c|c|}
\hline $\begin{array}{l}\text { Chapters and } \\
\text { sections of the } \\
\text { Work }\end{array}$ & $\begin{array}{l}\text { Ferdinand } \\
\text { Duchene//Russian } \\
\text { Version "Thamilla" }\end{array}$ & Vocabulary & $\begin{array}{l}\text { Jusupbek } \\
\text { Aymauytuly's } \\
\text { "Dameli" }\end{array}$ & Vocabulary \\
\hline & $\begin{array}{l}\text { Praise be to Allah, may } \\
\text { He be exalted! (preface) }\end{array}$ & 769 words & A few words (from translation) & 313 words \\
\hline Chapter 1 & Father & - & Father & - \\
\hline Section 1 & Engagement & 1278 & In the mountains & 1118 \\
\hline Section 2 & Marriage & 1610 & Wedding & 760 \\
\hline Section 3 & Love & 1658 & - & - \\
\hline Section 4 & Loan & 923 & Debt & 434 \\
\hline Section 5 & Account & 1057 & Taking into account & 890 \\
\hline Section 6 & Letter of attorney & 1013 & Letter of attorney & 1434 \\
\hline Section 7 & Akli against Thamilla & 1992 & Akylbai against Dameli & 423 \\
\hline Section 8 & Triumph of the pious Median & 359 & - & - \\
\hline Chapter 2 & Rival & - & - & - \\
\hline Section 1 & Distemper & 902 & - & - \\
\hline Section 2 & Mrs. Khadija & 1798 & Khadija Baibishe & 1075 \\
\hline Section 3 & Rival & 1549 & & \\
\hline Section 4 & Circle of love & 1446 & Next love & 1547 \\
\hline Section 5 & She or me & 1151 & Either she, or me & 1456 \\
\hline Chapter 3 & Lord & - & Bai & - \\
\hline Section 1 & Tirilt & 1355 & Tyrylt & 564 \\
\hline Section 2 & Wedding & 872 & Marry & 380 \\
\hline Section 3 & Indignation & 1241 & Revolt & 524 \\
\hline Section 4 & Meddahi & 910 & - & \\
\hline Section 5 & Bridled, subdued & 1036 & Bridled & 792 \\
\hline Section 6 & Child & 1344 & Child & 1290 \\
\hline Section 7 & Interference & 776 & - & \\
\hline Section 8 & Father and husband & 625 & Father and husband & 567 \\
\hline Chapter 4 & At liberty & - & - & - \\
\hline Section 1 & Makuda & 817 & - & - \\
\hline Section 2 & In the bush & 1008 & - & - \\
\hline Section 3 & In the woods & 1049 & - & - \\
\hline Section 4 & Dells & 1274 & - & - \\
\hline Section 5 & Piece of bread & 1093 & - & - \\
\hline Section 6 & Delis & 946 & Delis & 508 \\
\hline Total & & 31851 words & & 14075 words \\
\hline
\end{tabular}

By comparing the texts one can immediately note that the French and Russian versions of the novels begin with words of praise to Allah, while in the Kazakh variant this does not happen. When comparing textual and structural features it becomes clear that the work is shortened. The original contains 27 chapters and 31,851 words, and the translation consists of only 17 chapters and 14075 words. Judging by the extent of reductions, we can say that this is an abridged translation. The reason for this conclusion is not only the number of titles and vocabulary units, but also a huge reduction in the overall plot structure of the work. If we study the storylines of the two works by means of a comparative analysis, we shall see that the translator pursued only one purpose. For example, the chapters of the original makuda, in the woods, a piece of bread describe the fate and traditions of young women dancing at feasts of the rich and horse thieves in the woods. There is no such description in the translation. As Jusupbek Aimautuly said when translating his main concern was the inequality of women, an issue close to the Kazakh people and widely spread in the Kazakh society. Besides that he completely left out any characteristics concerning the life, traditions and national identity of Bedouins. Taking into account the national mentality of the Kazakh people, the writer drew attention to the ideas that were important to him. If one asks what parts were shortened in the translation we answer that the author excluded two chapters. Firstly, it is the chapter "Love", which describes the love relationship between Akylbay and the exchanged Dameli. Secondly, these are stories which depict troubles that occur in Arab society, such as horsestealing, girls' earning money by dancing, etc.

The reason for the exclusion of the love chapter is the fact that generally, young women exchanged for cattle do not like those who buy them and separate them from their loved ones. Both Arabs and Kazakh know similar situations. Exceptions are cases like that of Dameli who married an educated man. So we come to the conclusion that for this reason the author has excluded the love 
chapter. According to the requirements of a master translation, translators must not change the thoughts of the author of the original. They can change the external shape and norm, but they are always obliged to preserve the idea (Usup, 2011). We cannot stop wondering whether Jusupbek Aimautuly's mastery of the art of the Kazakh translation and the depth of his good sense was successful in conveying the basic idea. This is, for example, renaming of the noval "Thamilla" into the Kazakhname "Dameli", a thing that require separate study; this is the inventiveness of the writer in renaming his characters: Aklifor Akylbay, Meziane for Mazen, Munne for Zeine, Yamins for Jamila. Resourcefulness in finding analogues of foreign words, preservation of the overall story despite the succinct reduction, reproduction of the sequence of events and the tensions of the events demonstrate once again the many-faceted talents of the translator.

The second conclusion is the recognition of Arab shortcomings as superfluous and alien for Kazakh society. However, the reader, when reading the work of the author (translator) as a translated work will not get acquainted only with the ideas of the author, but with the culture and traditions of a foreign people. When translating one should not be allowed to change the national mentality and psychological characteristics of another people. This raises the question of why Jusipbek Aimautuly wholly excluded from the translation certain aspects of Arab life, such as different forms of existence and the principles and habits of this people? This work has lost a cognizable function in translation, yet from the ideological point of view it fulfilled its obligations. If we add to this the psychological, moral and aesthetic value and the literary-aesthetic power in the work, there is all the more reason to believe that the translation is impeccable.

\section{Discussion}

Translation is not just a way to educate, but also a deep link that brings nations together. Translation is a difficult task and requires true artistic skill. We can definitely and firmly say that Aimautuly perfectly carried out his obligations as a translator.

In Aimautuly's stories, there is a skillful translation of women's fate, women's equality, the rights of women with disabilities in society, their dreams, their sufferings as a result of an injury, true-life outlook and their vulnerability.

\section{Conclusion}

This analysis of the translation of foreign literature into Kazakh shows the exceptional professionalism of $\mathrm{J}$. Aimautuly as a translator, a public figure and a writer. Among the main motives, characteristics and peculiarities of the creative work of the translator Aimautuly, we can distinguish the following:

- Jusupbek's translations borrowed from Western literature that coincided with his ideological orientation and political positions

- J. Aimautuly, while translating, paid special attention to the obvious and simple description of the story, often resorting to the methods of using analogues and trying to apply, instead of the foreign language, units and elements that are more relevant to the Kazakh language

- Jusupbek's main reasons for translating Western literature come from the historical and social situation in the society, social similarities between two nations, and his goal to identify the shortcomings and ills of Kazakh society

- Jusupbek never translated stories haphazardly but carefully chose works of fiction that were needed for Kazakh society to awaken a mentality of reason; he chose events resonant with Kazakh life

- The writer in the process of translating fiction paid special attention to aspects that would be relevant to the Kazakh reader, imparting onto the translation a national character

- Jusupbek considered it important to write an accurate translation that translated specific objects or scientific terms in ways that conveyed the main idea even if it did absolutely coincide with the original text

- J. Aimautuly's principle "in the translation of fiction, accuracy is of paramount importance" does not indicate word for word or accurate translation. This means that one must convey the basic idea in detail, maintaining the content of the spiritual and cultural concept of a foreign country

- J. Aimautuly was against the forced translation of established terms into the Kazakh language, advising that the climb of culture onto a high level can only be accomplished by means of developing a natural and civilized language

\section{Acknowledgement}

The authors accord thanks to the Ministry of Education and Science of the Republic of Kazakhstan and L.N. Gumilyov Eurasian National University for the grant to accomplish this study.

\section{Funding Information}

The research is implemented on the basis of L.N. Gumilyov Eurasian National University by way of writing a $\mathrm{PhD}$ dissertation. 


\section{Author's Contributions}

Amanzhol Altay: Contribution to the writing of the Abstract, Introduction, and section "Results".

Saulesh Aituganova: Contribution to the Literature review, to translation into English, data collection and complying with the requirements of the journal.

Karlygash Aubakirova: Data collection, contribution to writing the sections "Discussion", "Results" and "Conclusion".

\section{Ethics}

The authors have read and approved the paper and no conflicts of interest in the publication of the paper.

\section{References}

Aimautuly, J., 1928. Damely. Kazmembas Press, KyzylOrda, pp: 119.
Aimautuly, J., 1925. Audarma Turaly. 1st Edn., Collection of Literary Articles.

Aimautuly, J., 1926. Balzhan. Journal "Leninshyl Zhas"

Kamzabekuly, D., 2002. Alash Zhane Adebiyet. Monograph, Foliant Press, Astana, pp: 24.

Kirabayev, S., 2002. Tauelsyzdyk Ruhymen. Foliant Press, Astana, pp: 504.

Momyshuly, B., 1961. Undy Halkynyn Uly Perzenty. Socialistic Kazakhstan (107).

Tagore, R., 1961. For the Centenary of his Birth. Eastern Literature Press, Moscow, pp: 362.

Usup, K., 2011. Korkem Audarma: Kyry men syry. Foliant Press, Astana, pp: 496. 